This item was submitted to Loughborough's Research Repository by the author.

Items in Figshare are protected by copyright, with all rights reserved, unless otherwise indicated.

\title{
The European Union and refugees: a struggle over the fate of Europe
}

\section{PLEASE CITE THE PUBLISHED VERSION}

http://dx.doi.org/10.1080/23340460.2017.1322252

\section{PUBLISHER}

Taylor \& Francis $@$ European International Studies Association

\section{VERSION}

AM (Accepted Manuscript)

\section{PUBLISHER STATEMENT}

This work is made available according to the conditions of the Creative Commons Attribution-NonCommercialNoDerivatives 4.0 International (CC BY-NC-ND 4.0) licence. Full details of this licence are available at: https://creativecommons.org/licenses/by-nc-nd/4.0/

\section{LICENCE}

CC BY-NC-ND 4.0

\section{REPOSITORY RECORD}

Bilgic, Ali, and Michelle Pace. 2019. "The European Union and Refugees: A Struggle over the Fate of Europe". figshare. https://hdl.handle.net/2134/24838. 


\title{
The European Union and Refugees: A Struggle over the Fate of Europe
}

\author{
Ali Bilgic and Michelle Pace \\ Accepted version to be published in Global Affairs \\ Europeans have illusions about who they are and what kind of conditions they are in.
}

Ai Weiwei, on how Europe engages with refugees, 2017

Mark Mazorow's (2009) The Dark Continent: Europe's Twentieth Century re-reads European history in an unconventional way: European history is not about democracy and human rights. Mazorow's argument challenges long held views that Europe is 'naturally' a cradle of democracy. On the contrary, fascism and communism - the former more than the latter - both had deep roots in European politics and societies. During the inter-war period in particular, most European states adopted policies that assaulted the rights of minorities and that limited migration as much as possible to keep their respective 'nations' clean and pure. Needless to say, Jewish refugees who attempted to escape racist and fascist policies in Germany and other countries were denied entry and asylum in several European countries, as well as in the United States of America. Most of these refugees had to return back to their countries of origin, only to be murdered in ghettos and gas chambers.

Political decisions about migration, particularly refugee movements, have never been just about migration. Such decisions tell us what kind of political projects are in effect to shape and construct a particular society: how a society can be imagined. In other words, how a political community deals with 'outsiders', who is defined as an 'outsider', and who is expelled from the said community - these issues concern what that community is and will be. During the inter-war years, the way 'Europe' - with its supposedly democratic, fascist, and communist regimes - perceived and addressed migration, especially those fleeing persecution, was a precursor to what type of social space Europe would be and how its destiny would be sealed.

In the 21st century, contestation over how migration should be governed is not just about 'migrants', 'welfare systems', 'asylum procedures', etc.: it is a struggle over the very meaning of Europe today.

In this commentary, we argue that the European Union (EU) faces a decision about its fate, Europe's fate for that matter, in the way in which it deals with protection-seeking migration flows 
from the Global South. One choice is to continue with 'business-as-usual', meaning sealing dubious 'deals' with 'neighbouring' countries to stop the movement of migrants and refugees towards EU borders, securitising human movements as threats to 'European citizens' freedoms and security', building walls, sending heavily armed boats to the Mediterranean, privatizing and outsourcing migration and asylum governance, and so on. It is high time to remind ourselves that this was the same pathway that European states followed during the inter-war period. The rise of ultra-right, racist, and xenophobic movements all over Europe is a direct result of this way of action: these are policies that have been implemented equally by centre parties, both from the right and the left. The rise of racism in Europe is a direct consequence of such exclusionary, securitizing and xenophobic migration policies of the EU and its member states' governments, which bandwagon onto the train of xenophobia rather than challenge it.

Another choice for the EU is to show political and normative leadership that will change the course of such migration governance processes. We are not naive to argue that this is an easy task, given the hegemony of current and ongoing anti-migration politics. However, we do argue that, in a world where democratic values and human freedoms have been under constant attack all over the world, the institution which defines its very existence through these values should take a position in accordance with these principles. If not, the EU is reducing its 'being' to a single 'white' market and 'Europe' as a continent will reverse back to its original roots: those that have been witnessed before in the form of colonialism, racial superiority, social Darwinism (engineering) and national purity. In that case, there will be no legitimacy of nor any need for the EU as it has been defined in the main up to this day.

Migration, especially refugee movement, is the point where the EU should hold the ground to preserve its own existence and 'Europe' by upholding democracy, human freedoms and equality. In the last section of the article, we will suggest how this can be actualised.

\section{Managing Migration as 'Business-as-Usual': the EU as a Border Guard of a Single 'White' Market}

The EU's responses to refugee movements have traditionally been policies regulating the right to seek asylum in EU territorial borders and policies that govern relations with neighbouring countries or with countries hosting high numbers of refugees. In practice, both types of policies aim at restricting refugees' freedom of movement and their universal right to seek asylum in a state that is a party to the Refugee Convention.

From the late 1990s onward, the EU has taken the path of limiting the freedom of movement of asylum-seekers within the EU through successive Dublin Conventions I, II, and III (Guild, 2006). In a nutshell, these regulations determine that asylum-seekers should remain in the EU member state where they have entered the EU in the first instance. These attempts to limit mobility of asylumseekers have resulted in, first, disagreements within the EU concerning member states on the borders carrying the highest 'burden' of refugees. Secondly, and as a recent political practice, some of the more recent member states, such as Hungary, stage their xenophobic, racist, and illegal policies from the point of international and EU laws as necessary to protect 'European civilisation' from terrorism and 'new barbarians'. The EU has been extremely ineffective in addressing both these problematic issues. 
Another common policy that has been adopted at the EU level is to militarise the EU's external borders and seas. Member states, such as Spain, built barbed-wire walls through EU funding; Frontex coordinates the militarised operations of member states in the Mediterranean to meet boats carrying irregular migrants, whose right to seek asylum is violently taken away from them either through 'push-back' operations or by wild natural and weather conditions capsizing boats and killing them (Gammeltoft-Hansen, 2006; Bilgic, 2013: 118-121). Although the EU Commission has attempted to integrate a humanitarian approach of 'saving lives' into its migration control policies as a result of rising criticisms and death tolls, it has been repeatedly proven that the EU-regulated and funded operations have had marginal effects on saving lives of migrants, if not making the situation worse for people fleeing persecution and war torn countries. 'According to the International Organisation for Migration, 24,513 people had landed in Italy this year (2017) by April 2nd. That was an increase of about $30 \%$ compared with the first three months of last year. Yet UNHCR, the UN refugee agency, calculates that the death rate per 100 arrivals climbed from 1.8 in 2015 to 3.4 in the first three months of 2017. One in 30 migrants in the central Mediterranean now dies en route'. $^{1}$

Regarding the EU's external relations, as EU practices of curtailing the influx of refugees and migrants to its collective shores become more deeply entrenched in its migration policy, we are witnessing a serious deterioration in global human rights frameworks. To start with, Turkey is by no means a safe third country that can guarantee protection of asylum seekers, as has been reported by Amnesty International and other international NGOs. ${ }^{2}$ Apart from applying for asylum, refugees should have access to education, healthcare, and employment. Additionally, considerations of 'safe country' should take into account that most of Turkey's 2.7 million refugees do not live in camps, but in off-the-grid urban settlements under marginal social conditions. The safety of refugees, we can argue, is also endangered in the cities on the Turkish-Syrian border, where most of these vulnerable humans are congregated. Orçun Ulusoy (2016) argues that deeming Turkey as a safe third country is highly problematic. He cites events in a small remote town in the east of Turkey, Askale, which hosts a "deportation" centre for irregular migrants. Unlawful practices of staff working at this centre - including, access to clients being arbitrarily blocked, clients' asylum applications being denied without proper examination, minors being kept in isolated cells without access to family members, and possible cases of ill treatment and torture - have been reported by local lawyers.

\footnotetext{
1 'Merciless Sea: The number of migrants crossing the Mediterranean keeps rising'. The Economist, 12 April 2017. Available at http://www.economist.com/news/europe/21720663-so-does-risk-death-numbermigrants-crossing-mediterranean-keepsrising?fsrc=scn/tw/te/bl/ed/mercilessseathenumberofmigrantscrossingthemediterraneankeepsrising

${ }^{2}$ The report is available at https://www.amnesty.org/en/latest/news/2016/03/eu-turkey-refugee-deal-ahistoric-blow-to-rights/
} 
Furthermore, there is no guarantee for its own citizens - for whom the state should be the sole sovereign guarantor. Erdogan's authoritarian practices have long been coming before the planning of the EU-Turkey deal was even underway. The European Commission launched a formal invitation to Turkey to start membership negotiations in October 2004, paving Turkey's path towards inclusion in this "exclusive club of democracies". Turkey's Recep Tayyip Erdogan, who became president in 2014, had served as the country's prime minister for 11 years. It took him only a few years after the official launching of Turkey's EU membership negotiations kicked off to veer away from a primary condition of the EU's offer: namely, to stay clear on the political reforms path that would lead Turkey to a democratic transition. A country that used to be hailed as a model of democracy for the Arab world became a case study of 're-authoritarianization' and more like a one-man autocracy unfortunately symptomatic of governance models in the Middle East rather than the country moving towards the "liberal" European democracy type. Erdogan's decade or so long authoritarian approach to governing Turkey only accelerated after the July 2016 attempted coup d'état, a few months after the signing of the EU-Turkey deal.

We are now therefore living and witnessing an age where refugees are being used as human currency and where rights of refugees are being traded for short-sighted political gains. It is now well over a year since the EU-Turkey "deal." The deal allows Greece to return to Turkey "all new irregular migrants" arriving after March 20, 2016. Greek authorities were required to set up new, expedited processes to receive, review and assess claims for asylum. In exchange, EU Member States agreed to increase resettlement of Syrian refugees residing in Turkey, accelerate visa liberalization for Turkish nationals, and boost existing financial support for Turkey's refugee population. The EU Asylum Procedures Directive requires that a person can only be readmitted to a 'safe third country' which can guarantee effective access to protection. According to the Plan, Turkey can be regarded as a 'safe third country'.

As well as the EU-Turkey deal, there has been the joint way forward with Afghanistan as well as migration "compacts" between the EU and Jordan and Lebanon. The EU agreement with the Afghan government allows its member states to deport an unlimited number of Afghanistan's asylum seekers, and obliges the Afghan government to receive them. The stick that the EU used for ensuring such an agreement was that Afghanistan would be stripped off its EU aid if the Afghan government did not cooperate. ${ }^{3}$ The deal was not made public but according to The Guardian the Afghan government committed to readmitting any Afghan citizen who was not granted asylum in Europe, and who refuses to return to Afghanistan voluntarily. This deal was secured in spite of the obvious human security concerns for such returnees. The Taliban continues to mount violent attacks in many parts of the country.

3 'EU's secret ultimatum to Afghanistan: accept 80,000 deportees or lose aid', The Guardian. 28 September 2016. Available at https://www.theguardian.com/global-development/2016/sep/28/eu-secret-ultimatumafghanistan-accept-80000-deportees-lose-aid-brussels-summit-migration-sensitive 
Afghanistan's government may well have had very little choice, with a domestic revenue of approximately $10.4 \%$ of GDP, and a high dependency on foreign aid. According to Liza Schuster (quoted in Rasmussen, 2016), who stresses that there has been very little by way of transparency in the negotiation process, this deal is a good example of "how developed countries are able to push through their agenda in countries where there simply isn't the capacity in the ministries to push back".

In the case of the EU-Lebanon compact, international NGOs including Human Rights Watch have raised serious and related concerns about widespread corporal punishment and inattentive teachers in Lebanese public schools' secondary shifts which Syrian refugee children attend, the lack of language support for classes taught in French and English as well as expensive transportation costs and lack of textbooks in some of these schools. As a result many Syrian children in Lebanon are dropping out of school.

The EU-Jordan compact is aimed at allowing up to 78,000 Syrian refugees permission to work. However, the requirement to provide a health certificate and an ID card in order to be eligible for work is no easy task for Syrian refugees. As of late July 2016, only 20,000 Syrians had been granted a work permit.

Similar, flawed, EU agreements are on the way with Nigeria, Mali, Ethiopia and Senegal, aimed at deporting migrants and refugees while blackmailing these dubious regimes with "humanitarian aid".

Sudan, a country that has been globally ostracized for human rights abuses, as well as for sponsoring terrorist activities, is now forging increasingly close ties with the EU.

In the frame of the EU's migration policy, these budding partnerships between the EU and authoritarian regimes are in part financial but they are also highly political. The deal demands of the EU's "partners" to curb migration and in return partners receive a financial package. In the case of Sudan for instance, the EU has so far given Sudan just under $€ 215$ million, $€ 38$ million higher than originally announced in July 2016. Meanwhile, Sudan, makes no secret of the fact that it is using an infamous government-aligned militia to arrest more migrants on its borders. EU officials argue that these funds are strictly aimed at supporting "humanitarian" efforts, but how are these funds bring tracked down? What is the EU's monitoring and evaluation procedure for ensuring that these funds are genuinely spent on the objectives they were designed for in the first place? Not only is the EU complicit in exacerbating the migration crisis further but through its provision of financial and other in kind support to authoritarian governments it is actually legitimizing them. Individual member states of the EU are also shoring up authoritarian regimes' "anti-migration" efforts. Germany allocated approximately $€ 12$ million towards projects aimed at stemming African migrants, who use Sudan as a transit route to Europe. In August 2016, Italy signed an agreement with Sudan designed to tackle migration, and three months later deported a group of Sudanese nationals attempting to cross into Italy from France.

In order to have a credible policy on asylum and border management and as an organization based on normative principles, the EU and its Member States are expected to respect the funda- 
mental ethical norm of the rule of rescue, not to push individuals in need into danger, which is at the heart of the UN Refugee Convention and its key article 33 on no push-backs or nonrefoulement:

Article 33(1) of the 1951 Geneva Convention provides that 'No Contracting State shall expel or return ("refouler") a refugee in any manner whatsoever to the frontiers of territories where his life or freedom would be threatened on account of his race, religion, nationality, membership of a particular social group or political opinion'.

The principle of non-refoulement is enshrined in EU law in Article 78(1) TFEU and Article 18 and 19 of the EU's Charter of Fundamental Rights (EUR-Lex, 2012). Judgments of the European Court of Justice (CJEU) and the European Court of Human Rights (ECtHR) have also consolidated the application of this principle in the EU.

In migration policy, the EU and its Member States's strategies of covering up the truth reveal a picture of migration governance through lies. How can we academics attempt to explain this lying? Why is a culture of lies seeping in and dominating European society? Why is the EU reinventing the reality that migrants and asylum seekers face and in the process denying facts? Why are facts being put out of reach of the general European populations? This shift towards a counter-factual European culture underlines a serious deterioration in the normative architecture that has been set up since the end of the World War II to guide the global community in its conduct of internal and external relations. But the reality we are witnessing today shows that international law serves to maintain privileged positions of great powers in the international system and works as a tool to uphold Western dominance in the post-colonial era. Meanwhile, facts are being distorted to justify the EU's deals. However, the post-factual politics that the EU has itself been engaging with is also undermining its being, its soft power, and its very foundations. The reintroduction of political and normative leadership of the EU is necessary not only to protect migrants in need of protection but also to preserve the EU's presence, actorness and effectiveness in global politics. If the EU fails this, the return of Europe to its original roots that led to colonialism, imperialism, racism, fascism, and consequently two world wars can destroy the EU and other political struggles that promote democracy, human freedoms and equality.

\section{Policy prescriptions in an age of post-factual politics}

In a climate of lies and fear mongering what responsible European leadership can do is to stop the tough discourse on migration control which continues to fan xenophobic attitudes and instead focus EU efforts on practical ways in which Europe can reach a hand to people suffering and dying at Europe's borders.

\section{Stop criminalizing the practice of saving lives}

In February 2017, the head of Frontex suggested that NGOs, which are relentlessly trying to prevent human deaths in the Mediterranean, were in effect 'supporting the business of criminal networks and traffickers in Libya through European vessels picking up migrants ever closer to the Lib- 
yan coast' (Castagna and Majkowska-Tomkin, 2017). This is hardly a surprise for those who are following the problems that NGOs or ships' captains have to face when they save human lives in distress in the Mediterranean.

The cost of the EU's migration control regime is dire and irregular migrants, such as three-year-old Aylan Kurdi, are paying a high price with their own lives. The EU should immediately take actions to decriminalize saving lives. The EU cannot continue to build its presence as a beacon of human rights and freedoms over the dead bodies of migrants.

\section{Create a platform of pro-migrant movements, not become a border guard}

In the area of migration, the EU has been reduced to an intergovernmental organization that follows some Member States' policies and implements them. Instead, the EU should create a democratic and pluralist platform to openly discuss and share information about migration and refugee movements in Europe. It is important to note that none of the information in regard to how little the percentage of refugees and asylum-seekers that EU member states have is in comparison to states from the developing world or how much worse the human suffering has become due to restrictive migration policies will affect the eyes that do not want to see or the hearts that do not wish to feel. This is a more serious problem in the age of post-factual policies where lies are comfortably used to justify policies. Racism and xenophobia feed post-factual politics and the EU is under threat too. That is why, for example, the Brexit campaign focused on controlling 'our' borders and Marie Le Pen explicitly campaigned on anti-immigration and anti-EU platforms. This is hardly a coincidence.

New political and normative leadership of the EU should re-organize its political alliances with grassroots movements and transnational pro-migrant movements, which actually defend and practice the EU's stated values. The EU should move beyond the platform of sharing 'biometric information of migrants' among security agencies of member states. It should become a platform which instead brings its real allies together to save the fate of Europe from falling into the grave mistakes of history.

\section{Sanctions against Europe's new 'border guards'}

Hungarian Prime Minister, Victor Orbán, argues that 'Muslim asylum seekers are at the roots of terrorism, crime, anti-Semitism, and homophobia in Hungary and Europe' (Korkut 2017). The EU Commission has recently sent the Commissioner for Migration, Home Affairs and Citizenship to Budapest for "serious" talks. During this said visit, the Commissioner argued that 'we are a union based on fundamental principles to help those in need of protection, in a human, dignified and respectful way' (Korkut, 2017).

In the last few years, Hungary has been sliding towards authoritarianism in spite of its membership of the EU. A racist and xenophobic, anti-immigration strand is the fundamental dimension of Orban's authoritarianism. Presenting himself and Hungary as the protector of 'European civilisa- 
tion' has been a way of deepening authoritarian practices in Hungary, and in regard to which development, the EU has chosen to remain silent. The latest victim of this process is the Central European University. As the history of Europe has proven again and again, racism and xenophobia first hit 'outsiders', the migrants, but in the end, these feelings always hit the 'self' back like a boomerang.

There is no European civilization but a contention about what it will be. 'European civilization' that people like Orban claim to protect is the contemporary version of colonialists, imperialists and racists of 19th century romanticism and social Darwinism, which led to the downfall of Europe. It is not the European civilization based on human rights, equality and freedoms. The EU must make a political decision about which European civilization it belongs to but it is worth remembering that there is no room for the EU in Orban's European civilization.

\section{Revoke migration deals with non-democratic regimes}

The EU-Turkey refugee deal is a continuation of the trend that the $\mathrm{EU}$ and its member states have been supporting in the last three decades. It aims to convert the neighbouring countries into European border guards to stop 'unwanted' migrants before they reach EU borders. Surely refugees have been one group of victims of these policies that have been part of the European Neighbourhood Policy since 2004, and the Euro-Mediterranean Partnership even before that, since 1995 in effect. However, there is something different and a more disturbing dimension of the EU-Turkey deal. As Kirsty Hughes so categorically argues 'Drawing neighbouring countries into membership through a process based on respect for democracy and rights has been one of the EU's more successful strategies. Yet in offering to open more negotiation chapters with Turkey, at a time when Turkey clearly no longer meets the EU'S democratic criteria, and when the EU is clearly no longer genuinely willing to consider Turkey as a future member state, makes the EU look hypocritical. Such a stance will surely weaken the influence the EU has over democratic reforms in western Balkan candidate countries.' (Hughes, 2016).

In other words, the EU has undermined its own political agency and credibility through such legally, politically and normatively dubious deals to stop refugee movements towards Europe. If the EU does not have the transformative power it was said to have anymore, what type of political power has this regional world society to show in order to require and legitimise its presence in regional as well as global politics? If the EU is to have some presence on the global scale, these 'deals' with non-democratic regimes must be revoked.

The EU thus faces a difficult political choice in the struggle for the fate of Europe: it will either continue with 'business-as-usual' in relation to refugees and diminish and become politically irrelevant in time or preserve its role and values through protecting 'human beings' who are not EU citizens but are badly in need of protection. These four-legged policy prescriptions that we offer here 
might well be non-practical or undoable ideals. However, there is no reason why International Relations scholars from Europe and the EU should not fight for them. Being normative and demanding ideals are not luxuries any more but necessities in this post-factual world of racist and xenophobic politics. If we do not, we will experience 'the Dark Continent' in our own time.

\section{References}

Bilgic, A. (2013). Rethinking Security in the Age of Migration: Trust and Emancipation in Europe. London: Routledge.

Castagna, G. and Majkowska-Tomkin, M. (2017). In the Mediterranean, Standing Back Is Not an Option. Open Society Foundations. Available at https://www.opensocietyfoundations.org/voices/coast-libya-standing-back-not-

op-

tion?utm source=news\&utm medium=email\&utm campaign=news 041517 \&utm content=DTTL yq7VVT2cgapTHrqm 41vkBjtOTb uvVjDfWXwN4

Gammeltoft-Hansen, T. (2006) 'Filtering Out the Risky Migrant: Migration Control, Risk Theory and the EU', Academy for Migration Studies in Denmark (AMID) Working Paper Series 52, Aalborg.

Guild, E. (2006). 'The Europeanization of Europe's Asylum Policy', International Journal of Refugee Law, 18:3-4, 630-651.

Hughes, K. (2016) 'Turkey, the European Union and the refugee crisis - a story of multiple failures.' Friends of Europe. Available at http://www.friendsofeurope.org/future-europe/turkey-theeuropean-union-and-the-refugee-crisis-a-story-of-multiple-failures/

Korkut, U. (2017), 'Open to those who can pay: the hypocrisy of how Hungary treats asylum seekers', The Conversation. Available at https://theconversation.com/open-to-those-who-can-pay-thehypocrisy-of-how-hungary-treats-asylum-seekers

Mazower, M. (2009). Dark continent: Europe's twentieth century. London: Vintage.

Rasmussen, S. E. (2016) 'EU signs deal to deport unlimited numbers of Afghan asylum seekers.' The Guardian. Available at https://www.theguardian.com/global-development/2016/oct/03/eueuropean-union-signs-deal-deport-unlimited-numbers-afghan-asylum-seekers-afghanistan

Ulusoy, O. (2016) 'Turkey as a Safe Third Country?' The Faculty of Law, University of Oxford, Border Criminologies, Blog. Available at https://www.law.ox.ac.uk/research-subject-groups/centrecriminology/centreborder-criminologies/blog/2016/03/turkey-safe-third 